\title{
Analisis Pengembangan Sumber Daya Manusia Dalam Perspektif Syariah
}

\author{
Anisatul Maghfiroh \\ Pascasarjana Ekonomi Syariah, Universitas Islam Negeri Sunan Ampel Surabaya \\ *Email korespondensi: anisatulmaghfiroh125@gmail.com
}

\begin{abstract}
Human Resources is something that is very influential for the progress of an institution. Without quality human resources, an institution will not develop and may even experience setbacks. Therefore, every organization must prepare a program that contains activities that can increase the capabilities and professionalism of human resources so that the organization can survive and develop in accordance with the organizational environment. This program is usually referred to as human resource development. Sharia are the laws that govern the relationship between humans and creators and creatures. This study aims to determine how the Islamic perspective on human resource development. This study is a literature review using sharia as an approach, namely examining the problem with books and scientific works. The results of this study indicate that human resource development in the persective of sharia is a development in the form of training in skills, knowledge, behavior and sharia competence.
\end{abstract}

Keywords: Human Resource Development; Sharia.

Saran sitasi: Maghfiroh, A. (2021). Analisis Pengembangan Sumber Daya Manusia Dalam Perspektif Syariah. Jurnal Ilmiah Ekonomi Islam, 7(01), 403-411. doi: http://dx.doi.org/10.29040/jiei.v7i1.2138

DOI: http://dx.doi.org/10.29040/jiei.v7i1.2138

\section{PENDAHULUAN}

Sumber Daya Manusia merupakan suatu hal yang sangat berpengaruh bagi kemajuan suatu lembaga. Tanpa sumber daya manusia yang berkualitas suatu lembaga tidak akan berkembang bahkan bisa mengalami kemunduran. Sumber daya manusia juga merupakan investasi sangat berharga bagi sebuah organisasi yang perlu dijaga. Setiap organisasi harus mempersiapkan program yang berisi kegiatan yang dapat meningkatkan kemampuan dan profesionalisme SDM supaya organisasi bisa bertahan dan berkembang sesuai dengan lingkungan organisasi. Untuk mencapai produktivitas yang maksimum, organisasi harus menjamin dipilihnya tenaga kerja yang tepat dengan pekerjaan serta kondisi yang memungkinkan mereka bekerja optimal.

Pengembangan sumber daya manusia pada hakikatnya merupakan salah satu unsur dari pembangunan manusia. Notoatmojo memberikan definisi pengembangan sumber daya manusia secara makro adalah suatu proses peningkatan kualitas atau kemampuan manusia dalam rangka mencapai tujuan pembangunan bangsa. Proses peningkatan ini mencakup perencanaan, pengembangan dan pengelolaan sumber daya manusia, sedangkan pengembangan sumber daya manusia secara mikro adalah suatu proses perencanaan pendidikan, pelatihan dan pengelolaan tenaga atau karyawan untuk mencapai suatu hasil optimal.

Dengan demikian pengembangan sumber daya manusia merupakan suatu proses peningkatan keterampilan atau kemampuan kerja karyawan pada saat sekarang dan mengantisipasi perubahan bisnis pada saat yang akan datang, dan pada akhirnya dapat meningkatkan kualitas sumber daya manusia.

Syariah adalah hukum-hukum yang mengatur hubungan manusia dengan Khalik maupun dengan makhluk, didalamnya terdapat dua unsur, yakni Ibadah dan Muamalah. Ibadah secara bahasa memiliki arti mematuhi, tunduk, dan berdoa. Dan secara istilah kata ibadah adalah kepatuhan atau ketundukan kepada dzat yang memiliki puncak keagungan, Allah SWT, sehingga ibadah juga merupakan tujuan hidup manusia.

Dengan demikian, timbullah suatu permasalahan yang akan dikaji oleh penulis, yaitu bagaimana 


\section{Jurnal Ilmiah Ekonomi Islam, 7(01), 2021, 404}

pandangan syariah mengenai pengembangan sumber daya manusia dalam suatu organisasi, jika ibadah merupakan tujuan hidup, sedangkan manusia dituntut untuk meningkatkan potensinya dalam bekerja.

Berdasarkan permasalahan di atas, artikel ini akan membahas pengembangan sumber daya manusia dalam perspektif syariah.

\section{Definisi Pengembangan Sumber Daya Manusia}

Setiap perusahaan atau lembaga dituntut untuk peka dan siap terhadap perubahan. Dan dalam menghadapi perubahan tersebut tidak lepas dari peran manusia. Sumber daya manusia tersebut dituntut untuk bisa menyesuaikan dengan perubahan lingkungan. Oleh sebab itu, agar dapat menyesuaikan dengan perubahan, SDM tersebut perlu dikembangkan potensi kemampuan dan kualitasnya.

Menurut Moekijat pengembangan adalah usaha untuk memperbaiki pelaksanaan pekerjaan yang sekarang maupun yang akan datang dengan memberikan informasi, mempengaruhi sikap atau menambah kecakapan.

Menurut Sastradipoera pengembangan sumber daya manusia mencakup baik pendidikan yang meningkatkan pengetahuan umum dan lingkungan keseluruhan maupun pelatihan yang menambah keterampilan dalam melaksanakan tugas yang spesifik.

Memahami pentingnya pengembangan dalam suatu organisasi, maka menjadi alternatif bagi suatu organisasi untuk terus meningkatkan prestasi kerja melalui pemberian peluang kebijakan pimpinan untuk mengikut sertakan karyawan mengikuti pelatihan dan pengembangan.

Mulawarman menyatakan pentingnya pelatihan dan pengembangan bagi individu sumber daya manusia untuk meningkatkan potensi dan kompetensi dalam menghasilkan hasil kerja yang efisien dan efektif sebagai bagian dari dukungan terwujudnya sinergi kerja yang berkualitas bagi suatu organisasi.

Tidak dipungkiri bahwa keberadaan pelatihan dan pengembangan bagi suatu organisasi diperlukan sebagai suatu proses bagi individu sumber daya manusia dalam meningkatkan prestasi kerja untuk mencapai tujuan organisasi, sehingga semestinya setiap organisasi untuk maju dan berkembang senantiasa memperhatikan dan mempertimbangkan kebutuhan pelatihan dan pengembangan dalam meningkatkan prestasi kerja.

Pengembangan sumber daya manusia pada hakikatnya merupakan salah satu unsur dari pembangunan manusia. Pembangunan manusia menyangkut partisipasi manusia dalam proses pembangunan suatu negara yaitu pembangunan dari manusia, oleh manusia dan untuk manusia.

Notoatmojo memberikan definisi pengembangan sumber daya manusia secara makro adalah suatu proses peningkatan kualitas atau kemampuan manusia dalam rangka mencapai tujuan pembangunan bangsa. Proses peningkatan ini mencakup perencanaan, pengembangan dan pengelolaan sumber daya manusia, sedangkan pengembangan sumber daya manusia secara mikro adalah suatu proses perencanaan pendidikan, pelatihan dan pengelolaan tenaga atau karyawan untuk mencapai suatu hasil optimal.

Rachbin mengemukakan bahwa pengembangan sumber daya manusia merupakan proses untuk meningkatkan pengetahuan manusia, keahlian dan keterampilan serta kemampuan orang-orang dalam masyarakat.

Nawawi menjelaskan bahwa perbedaan pelatihan dan pengembangan sumber daya manusia terletak pada fokus kegiatannya, yaitu pada fokus kegiatan pelatihan adalah untuk meningkatkan kemampuan kerja dalam memenuhi kebutuhan tuntutan cara bekerja yang paling efektif pada masa sekarang.

Sedangkan pada fokus kegiatan pengembangan sumber daya manusia adalah untuk mempertahankan dan meningkatkan eksistensi atau perusahaan sebagai usaha mengantisipasi tuntutan bisnis di masa mendatang.

Menggison dkk memberikan definisi sebagai inti proses pengembangan sumber daya manusia, yaitu;

1. Pelatihan adalah usaha sistematis untuk mengalihkan pengetahuan atau keahlian dari seorang yang tahu dapat melakukan sesuatu ke orang yang tidak tahu atau tidak dapat melakukannya.

2. Pengembangan adalah proses yang panjang untuk meningkatkan potensi dan efektifitas.

3. Belajar adalah proses yang tidak ada habisnya dalam mengubah diri dari keadaan semula.

4. Pendidikan biasanya dilihat sebagai struktur belajar yang terencana dengan tujuan untuk melatih pikiran.

5. Pengembangan sumber daya manusia adalah istilah yang digunakan untuk menjelaskan pendekatan yang terintegrasi dan holistik untuk mengubah perilaku kerja dengan menggunakan teknik dan strategi belajar. 


\section{Jurnal Ilmiah Ekonomi Islam, 7(01), 2021, 405}

Berdasarkan uraian sebelumnya, dapat disimpulkan bahwa pengertian pengembangan sumber daya manusia merupakan suatu proses peningkatan keterampilan atau kemampuan kerja karyawan pada saat sekarang dan mengantisipasi perubahan bisnis pada saat yang akan datang, dan pada akhirnya dapat meningkatkan kualitas sumber daya manusia.

Sebagaimana firman Allah SWT. dalam surat al-Alaq 1-5 sebagai berikut:

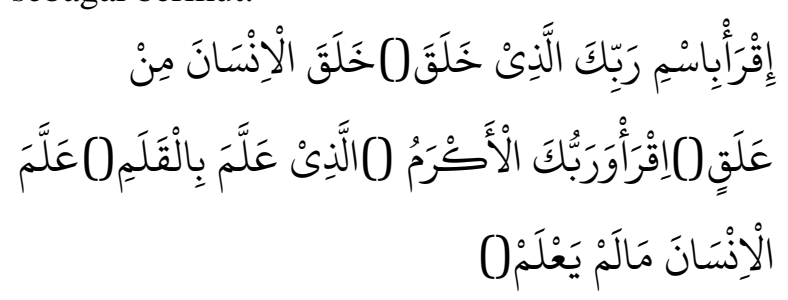

Artinya: "Bacalah dengan nama Tuhanmu yang telah menciptakan. Dia menciptakan manusia dari segumpal darah. Bacalah, dan Tuhanmulah yang Maha Pemurah, yang mengajari (manusia) dengan perantaraan kalam. Dia mengajari manusia apa yang belum diketahuinya." (QS. alAlaq:1-5).

Ayat tersebut menjelaskan bahwa pendidikanlah sangat penting. Dimulai dengan membaca, orang bisa memiliki pengetahuan, dan dari pengetahuan yang dimiliki bisa berkreasi dan menghasilkan sesuatu yang bernilai. Oleh karena itu, untuk meningkatkan kualitas manusia, maka manusia harus belajar, dalam artian mengembangkan ilmu yang telah dimiliki sehingga menghasilkan sesuatu yang bernilai dan bisa bermanfaat buat manusia yang lain. Dan tidak hanya kualitas kemampuan intelektual saja yang dikembangkan namun kualitas keimanan juga harus dikembangkan, dan semua itu bisa dilakukan dengan memperbanyak ilmu pengetahuan.

\section{Tujuan dan Manfaat Pengembangan}

Pengembangan karyawan bertujuan dan bermanfaat bagi perusahaan, karyawan, konsumen atau masyarakat yang mengkonsumsi barang/jasa yang dihasilkan perusahaan. Tujuan pengembangan menurut Hasibuan hakikatnya menyangkut hal-hal berikut:

a. Produktifitas kerja. Melalui pengembangan, produktivitas kerja karyawan akan meningkatkan kualitas dan kuantitas produksi semakin baik, karena technical skill, human skill, dan manajerial skill karyawan yang semakin baik. b. Efisiensi. Untuk meningkatkan efisiensi tenaga, waktu, bahan baku dan mengurangi ausnya mesinmesin, pemborosan berkurang, biaya produksi relative kecil sehingga daya saing perusahaan semakin besar.

c. Kerusakan. Mengurangi kerusakan barang, produksi dan mesin-mesin karena karyawan semakin ahli dan terampil dalam melaksanakan pekerjaannya.

d. Kecelakaan. Tingkat kecelakaan karyawan dapat dikurangi sehingga jumlah biaya pengobatan yang dikeluarkan perusahaan berkurang.

e. Pelayanan. Peningkatan pelayanan yang lebih baik dari karyawan kepada nasabah perusahaan karena pemberian pelayanan yang baik merupakan daya penarik yang sangat penting bagi rekanan-rekanan perusahaan yang bersangkutan.

f. Moral. Dengan pengembangan, moral karyawan akan lebih baik karena keahlian dan keterampilannya sesuai dengan pekerjaannya sehingga mereka antusias untuk menyelesaikan pekerjaannya dengan baik.

g. Karir. Keterampilan untuk meningkatkan karir karyawan semakin besar, karena keahlian, keterampilan dan prestasi kerjanya lebih baik. Promosi ilmiah biasanya didasarkan kepada keahlian dan prestasi kerja seseorang.

h. Konseptual. Manajer semakin cakap dan cepat dalam mengambil keputusan yang lebih baik karena technical skill, human skill, dan manajerial skillnya baik.

i. Kepemimpinan. Kepemimpinan seorang manajer akan lebih baik, human relationsnya lebih luwes, motivasinya lebih terarah sehingga pembinaan kerjasama vertical dan horizontal semakin harmonis.

j. Balas jasa. Balas jasa (gaji, upah, insentif, benefit) karyawan akan meningkat karena prestasi kerja mereka semakin besar.

k. Konsumen. Memberikan manfaat yang baik bagi masyarakat konsumen karena mereka akan memperoleh barang atau pelayanan yang lebih bermutu.

Manfaat yang perusahaan peroleh dalam melaksanakan penyelenggaraan suatu pelatihan adalah sebagai berikut:

a. Peningkatan produktivitas kerja organisasi sebagai keseluruhan antara lain karena tidak terjadinya pemborosan, karena kecermatan melaksanakan tugas, tumbuh suburnya kerjasama antar berbagai 
satuan kerja yang melaksanakan berbagai kegiatan yang berbeda dan bahkan spealistik, meningkatnya tekad mencapai sasaran yang telah ditetapkan serta lancarnya koordinasi sehingga organisasi bergerak sebagai suatu kesatuan yang bulat dan utuh.

b. Terwujudnya hubungan yang serasi antara atasan dan bawahan antara lain karena adanya pendelegasian wewenang, interaksi yang didasarkan pada sikap dewasa yang baik secara teknikal maupun intelektual, saling menghargai dan adanya kesempatan bagi bawahan untuk berpikir dan bertindak secara inovatif.

c. Terjadinya proses pengambilan keputusan yang lebih cepat dan tepat karena melibatkan para pegawai yang bertanggung jawab menyelenggarakan kegiatan-kegaiatan operasional dan tidak sekedar diperintahkan oleh manajer.

d. Meningkatkan semangat kerja seluruh tenaga kerja dalam organisasi dengan komitmen organisasional yang lebih tinggi.

e. Mendorong sikap keterbukaan manajemen melalui penerapan gaya manajemen yang partisipatif.

f. Memperlancar jalannya komunikasi yang efektif yang pada gilirannya memperlancar proses perumusan kebijaksanaan organisasi dan operasionalisasinya.

g. Penyelesaian konflik secara fungsional yang dampaknya adalah tumbuh suburnya rasa persatuan dan suasana kekeluargaan di kalangan para anggota organisasi.

\section{Prinsip-Prinsip Pengembangan}

Prinsip-prinsip pengembangan karyawan yang akan digunakan sebagai pedoman dalam mengembangkan karyawan agar berjalan dengan baik menurut Soeprihanto antara lain:

a. Adanya dorongan motivasi dari trainer, misalnya persiapan transfer atau promosi.

b. Adanya laporan kemajuan (program report).

c. Adanya penguatan (reinforcement).

d. Adanya partisipasi aktif dari trainer (active participation).

e. Latihan diberikan sebagian demi sebagian (participle oflearning).

f. Latihan harus mengingat adanya perbedaan individual (individual idifferent).

g. Trainer yang selektif (mau dan mampu)

h. Diusahakan trainer method yang sesuai.

\section{BEBERAPA METODE PENGEMBANGAN}

Pelaksanaan pengembangan harus didasarkan pada metode-metode yang telah ditetapkan dalam program pengembangan perusahaan. Program pengembangan ditetapkan oleh penanggung jawab pengembangan, yaitu manajer personalia dan atau suatu tim. Dalam program pengembangan telah ditetapkan sasaran, proses, waktu dan metode pelaksanaannya.

Supaya lebih baik program ini hendaknya disusun oleh manajer personalia dan atau suatu tim serta mendapat saran, ide, maupun kritik yang bersifat konstruktif.

Metode-metode pengembangan harus didasarkan kepada sasaran yang ingin dicapai.

Sasaran pengembangan karyawan adalah:

a. Meningkatkan kemampuan dan keterampilan teknis mengajarkan pekerjaan atau technical skill.

b. Meningkatkan keahlian dan kecakapan memimpin serta mengambil keputusan atau managerial skills dan conceptual skills.

Metode pengembangan Sumber Daya Manusia menurut I Komang Ardana dititikberatkan pada metode latihan yang meliputi:

a. Metode latihan bagi karyawan non managerial:

1) On the Job Method (dalam pekerjaan) meliputi:

a.On the Job

b. Appreticeship

2) Off the Job Method (diluar pekerjaan).

b. Metode latihan bagi karyawan managerial meliputi:

1) On The Job Method (dalam pekerjaan).

a) Belajar dari pengalaman

b) Coaching

c) Understudy (magang)

d) Position ratation/Tour of duty

e) Proyek khusus dan task force

f) Penugasan dalam bentuk panitia.

g) Bacaan selektif.

2) Off the job methods (di luar pekerjaan) meliputi:
a) Kursus-kursus
b) Role playing
c) Simulasi
d) Sentivity training (latihan kerja).
e) Special meeting (pertemuan khusus).
f) Multiple management. 


\section{TINJAUAN TENTANG PENGEMBANGAN SDM PERSPEKTIF SYARIAH}

Sumber Daya Manusia mumpuni yang mampu menjalankan bisnis dengan baik sangat diperlukan untuk mendorong perkembangan industri perkembangan syariah. Untuk menciptakan SDM tersebut, perbankan syariah pun hendaknya dapat meluangkan sejumlah dana untuk mendidik SDM sejak awal.

Sumber Daya Manusia yang berkompeten dapat dipastikan akan mencapai tujuan organisasi, dan sebaliknya, jika sumber daya manusia yang dimiliki oleh suatu perusahaan tidak berkompeten, perusahaan tersebut akan stagnan.

Pengembangan sumber daya manusia merupakan suatu proses peningkatan keterampilan atau kemampuan kerja karyawan pada saat sekarang dan mengantisipasi perubahan bisnis pada saat yang akan datang, dan pada akhirnya dapat meningkatkan kualitas sumber daya manusia.

Pada manajemen training syariah, di samping soft skill, dan hard skill, juga terdapat satu faktor penting yang perlu terus dijaga dan dikembangkan yaitu syariah skill atau juga dapat dipahami sebagai syariah competence. Syariah competence lebih dimaknai sebagai suatu kompetensi yang dibutuhkan para karyawan di industry syariah. Pada praktiknya, hal tersebut diwujudkan sebagai suatu rangkaian program pelatihan dan workshop mengenai tauhid (akidah), syariah (ibadah, muamalah), dan akhlak sebagai suatu kesatuan.

Kualitas sumber daya manusia dalam Islam terletak pada fondasi tauhid. Tauhid adalah fondasi keimanan seseorang yang menjadi basis pemahaman keagamaan seluruh umat Islam. Tauhid yang dimaksud adalah keyakinan bahwa hanya Allah yang berhak disembah, ditakuti, diharapkan dan takdir-Nya segala hal harus dikembalikan. Sebagaimana tauhid yang diikrarkan nabi Ibrahim dalam firman Allah surat al-an'am ayat 162 .

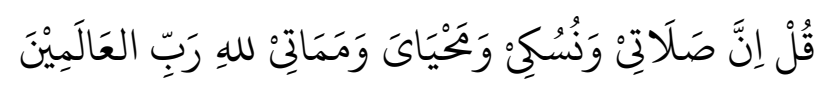

Artinya: "Katakanlah: "sesungguhnya shalat, ibadah, hidup, dan matiku hanyalah untuk Allah, Tuhan semesta alam.” (QS. al-an'am:162).

Tauhid inilah yang membuat setiap orang beriman merasakan keamanan dan ketenteraman dalam segala aktivitasnya. Sebagaimana firman Allah dalam surat al-an'am ayat 82 :

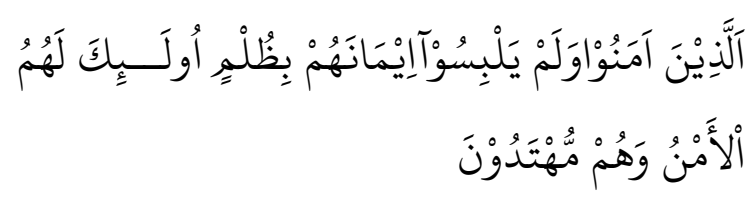

Artinya: "Orang-orang yang beriman dan tidak mencampuradukkan iman mereka dengan syirik, mereka itulah orang-orang yang mendapat rasa aman dan mereka mendapat petunjuk." (QS. alAn'am: 82).

Untuk memajukan kualitas Sumber Daya Manusia yang syariah ada tiga dimensi yang harus diperhatikan, yaitu:

a. Dimensi kepribadian. Dimensi kepribadian menyangkut kemampuan untuk menjaga integritas, termasuk sikap, tingkah laku, etika dan moralitas. Pribadi yang tangguh akan kuat bertahan dalam segala situasi dan kondisi yang dialami perusahaan. Meningkatkan dimensi ini berarti juga memberikan pelatihan untuk meningkatkan kualitas siddiq dan amanah. Di sisi lain mengutip Iqbal yang berpendapat bahwa untuk mencapai insane kamil atau manusia seperti karakter Rasulullah diperlukan tiga hal, yaitu pertama ketaatan pada hukum, kedua penguasaan diri sebagai bentuk tertinggi kesadaran diri tentang pribadi dan ketiga khalifahan ilahi. Jika karyawan taat hukum, maka tidak ada pencurian atau korupsi dalam perusahaan. Taat hukum ini tidak lain adalah kualitas yang diperlukan dalam karakter amanah. Jika karyawan menyadari kekhalifahan yang ada dalam dirinya maka tanggung jawabnya akan besar. Semuanya ini akan didapatkan melalui peningkatan dimensi kepribadian.

b. Dimensi produktivitas. Dimensi produktivitas menyangkut apa yang dapat dihasilkan oleh manusia tadi dalam hal jumlah yang lebih banyak dan kualitas yang lebih baik. Dimensi ini sudah sejak revolusi industri diperhatikan dalam meningkatkan kemampuan Sumber Daya Manusia perspektif Syariah. Dengan memberikan pelatihan yang ditujukan pada dimensi produktivitas, maka selain berbuah efisiensi dan output yang lebih baik, aspek fathonah dan tabligh juga tersentuh. Produktivitas individu dapat ditingkatkan menjadi produktivitas tim, karena kerja tim merupakan hal yang akhir-akhir ini mendapat perhatian besar dari perusahaan. Jika akhir-akhir ini banyak perusahaan yang mengunggulkan kerja tim untuk 


\section{Jurnal Ilmiah Ekonomi Islam, 7(01), 2021, 408}

meningkatkan produktivitas, dalam Islam hal itu bukanlah sesuatu yang baru.

c. Dimensi kreativitas. Dimensi Kretivitas menyangkut kemampuan seseorang untuk berpikir dan berbuat kreatif, menciptakan sesuatu yang berguna bagi dirinya dan masyarakatnya. Dengan berkembangnya industri kreatif akhirakhir ini, maka dimensi kreativitas harus mendapat sorotan khusus. Latihan yang ditujukan untuk dimensi kreativitas dapat meningkatkan kecerdasan berpikir dan berkreasi yang amat diperlukan dalam meningkatkan daya saing perusahaan.

Allah menyuruh Nabi untuk memperbaiki kondisi dan skill umat dengan cara memberikan kepada mereka latihan-latihan atau training. Untuk menambah keimanan, mereka pun memerlukan training. Sebagaimana firman Allah dalam surat anNahl ayat 125:

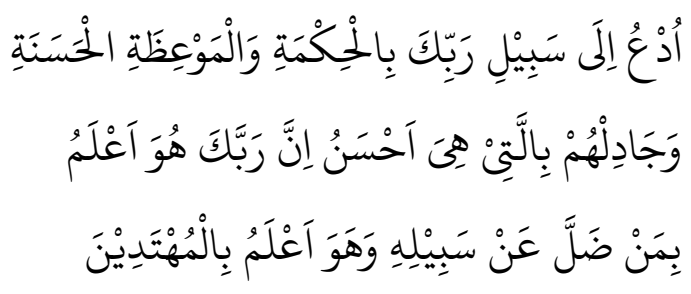

Artinya: "Serulah (manusia) kepada jalan Tuhanmu dengan hikmah dan pengajaran yang baik, dan berdebatlah dengan mereka dengan cara yang baik. Sesungguhnya Tuhanmu, Dialah yang lebih mengetahui siapa yang sesat dari jalan-Nya dan dialah yang lebih mengetahui siapa yang yang mendapat petunjuk”. (QS. anNahl: 125).

Pada dasarnya, tidak ditemukan secara pasti tentang pola pelatihan dan pembinaan karyawan di zaman Rasulullah SAW secara formal. Namun, kendatipun demikian bukan berarti sejarah Islam tidak memiliki tradisi pembinaan dan pelatihan kepada umat pendukungnya. Pola pembinaan dan pelatihan Rasulullah SAW diwujudkan dalam empat jenis metode, diantaranya adalah:

a. Metode Tilawah, konsep tilawah memiliki makna membaca. Metode ini diarahkan untuk membaca ayat-ayat Allah SWT. Implikasi praktisnya dapat dikemukakan bahwa membudayakan membaca al-Qur'an adalah salah satu bentuk pembinaan psikologis kepada pekerja muslim.

b. Metode Taklim, taklim adalah proses transfer dan transformasi dari pihak pertama kepada pihak kedua. Implikasi praktis teologisnya dengan memberikan pola pendidikan dengan cara membacakan dan mengajarkan kepada karyawan tentang etos kerja menurut kitab suci al-Qur'an. Sedangkan dimensi operasional perusahaan, taklim dapat dimaknai perlunya sosialisasi nilainilai, teori-teori, kiat-kiat sukses, kiat kerja produktif, aturan atau tata tertib yang ada di lingkungan perusahaan secara intensif, bahkan mungkin juga periodik, sehingga setiap karyawan bisa disegarkan kembali tentang pemahaman, visi dan misi, juga tugas dan kewajibannya di lingkungan kerja.

c. Metode Tazkiyyah, konsep ini dimaknai sebagai satu kemampuan memisahkan atau membersihkan. Implikasinya adalah memberikan pelatihan dan pendidikan kepada karyawan dengan tujuan untuk melakukan eliminasi perilaku-perilaku yang baik dan buruk atau kinerja yang baik atau buruk. Pola tazkiyyah ini, untuk proses pendidikan dan pembinaan dikembangkan dengan menggunakan hasil atau data evaluasi. Pemimpin perusahaan secara cerdas harus memberikan penjelasan yang kritis kepada karyawannya tentang peta hasil kerja mereka untuk melakukan kategorisasi jenis dan sifat perilaku yang harus diperbaiki.

d. Metode hikmah, konsep hikmah biasa digunakan untuk menunjukan pengetahuan filosofis. Pendekatan hikmah yang dikemukakan adalah sebuah pendekatan yang memiliki karakter terhadap sebuah kemampuan dalam menarik pelajaran tersembunyi dari sebuah kejadian.

Pengembangan diri (self-development) tidak dapat dipisahkan dari tujuan hidup manusia. Secara mudah dapat dikatakan bahwa bagi seorang muslim capaian maksimal adalah mendapatkan kebahagiaan dunia dan kebahagiaan akhirat, karena tujuan hidupnya hanya Allah SWT. Untuk ini visi kehidupan (bekerja) adalah mendapatkan ridho-Nya, sehingga dalam perjalanan hidupnya, manusia harus selalu dalam koridor syariah.

Setiap manusia dilahirkan dengan sifat atau bakat bawaan yang perkembangannya tergantung pada kapasitas dirinya, lingkungan dan pengaruh-pengaruh eksternal lainnya. Dengan semua keunikannnya, pengembangan diri berarti meningkatkan kemampuan dan potensi diri ke arah yang lebih baik, baik dari segi posisi atau jabatan, capaian, peluang dan manfaat. Dalam perusahaan, pengembangan diri karyawan atau 
career development tidak dapat dilakukan oleh karyawan itu sendiri sekalipun tanggung jawab yang lebih besar ada pada dirinya. Kegiatan ini melibatkan tiga pihak, individu itu sendiri, atasan langsungnya dan organisasi perusahaan. Peran paling besar tentunya ada pada individu itu sendiri. Dari perspektif Islam, yang berperan bukanlah tiga pihak itu saja, melainkan ada yang keempat yaitu Allah SWT.

Tabel berikut mencoba menghubungkan tahapan karier, pengembangan diri, dan dukungan apa yag diharapkan individu dari atasan langsung serta organisasi. Dukungan atasan atau organisasi ini diberikan dalam setiap tahap karier dan disesuaikan dengan kebutuhan individu pada waktu itu.

\section{Tabel 1}

Tahapan Karier, Pengembangan Diri, dan Dukungan

\begin{tabular}{|l|l|c|}
\hline Tahapan Karier & $\begin{array}{c}\text { Pengembangan } \\
\text { Diri }\end{array}$ & $\begin{array}{c}\text { Dukungan } \\
\text { Atasan/Organisasi }\end{array}$ \\
\hline Eksplorasi & $\begin{array}{l}\text { Dzikir Self-Memberi Informasi } \\
\text { Discovering }\end{array}$ & Memberi Saran \\
\hline Establishment & Self Motivation & $\begin{array}{l}\text { Memberi umpan } \\
\text { balik kerja }\end{array}$ \\
\hline
\end{tabular}

Syariah adalah hukum-hukum yang mengatur hubungan manusia dengan Khalik maupun dengan makhluk, didalamnya terdapat dua unsur, yakni Ibadah dan Muamalah. Ibadah secara bahasa memiliki arti mematuhi, tunduk, dan berdoa. Dan secara istilah kata ibadah adalah kepatuhan atau ketundukan kepada dzat yang memiliki puncak keagungan, Allah SWT. Ibadah juga merupakan tujuan hidup manusia. Hal ini dijelaskan dalam al-Qur'an surat adz-Dzariyat ayat 56:

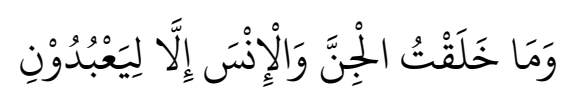

Artinya: "Dan aku tidak menciptakan jin dan manusia melainkan supaya mereka menyembahKu. " (QS. adz-Dzaariyat:56).

Tujuan yang diarahkan dalam al-Qur'an dan kemampuan menguatkan hubungan antara manusia dan Tuhannya adalah beribadah hanya kepada Allah. Dengan demikian, ada konsep hamba dan Tuhan. Hamba menyembah dan Tuhan disembah. Seorang hamba akan mampu menjalani hidupnya dengan baik selama ia mampu memahami dan mengaplikasikan konsep tersebut.

Muamalah berasal dari kata yang semakna dengan mufa'alah (saling berbuat), yang menggambarkan adanya suatu aktivitas manusia untuk memenuhi kebutuhan hidup sehari-hari. Manusia memiliki fungsi organisme fungsional yang sifatnya visual, seperti pancaindra dan pusat kesadaran pikir dan rasa, yakni roh keduanya bekerja mengikuti hukum yang sudah ditata sedemikian rupa dan telah ditentukan oleh Allah SWT, sehingga manusia sebagai makhluk yang diciptkan di muka bumi semata-mata untuk beribadah kepada-Nya dalam pengertian manajemen berarti harus mampu mengelola hidupnya dengan baik dan benar sesuai dengan apa yang diinginkan dan diperintahkan oleh Allah SWT baik dalam konteks hidup di dunia, apalagi kaitannya dengan akhirat yang jauh lebih penting untuk diprioritaskan.

Demikianlah Allah SWT telah menciptakan manusia sebagai makhluk yang paling sempurna, yang terdiri dari berbagai unsur yang terorganisasi dengan rapi dan interaksi antar unsur-unsur yang ada mencerminkan suatu sistem manajemen yang sangat sempurna dan canggih. Sudah seharusnya manusia menjadikannya sebagai I'tibar dalam membangun suatu sistem organisasi dan manajemen yang baik.

Ajaran Islam tidak mengenal adanya kelas manajer, karena adanya sekelompok orang yang berfungsi sebagai manajer hanya dapat dilihat dari pembagian kerja, atas dasar persetujuan bersama, atau atas dasar kemampuan manajerial semata. Di sini Islam hanya mengenal konsep pembagian kerja yang didasarkan pada kemampuan fisik, ilmu dan teknologi yang dimiliki oleh masing-masing manusia. Adanya jenjang-jenjang dalam organisasi kerja hendaknya semata-mata dimaksudkan agar setiap potensi, baik potensi fisik, ilmu dan teknologi dapat disinergikan. Sebagaimana firman Allah Surat az-Zukhruf ayat 32:

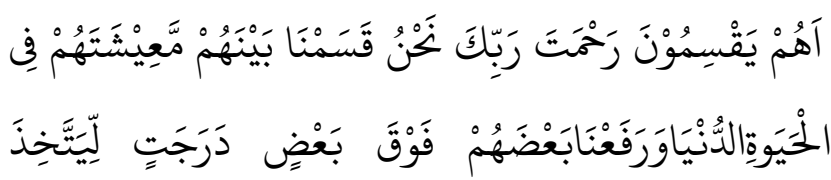

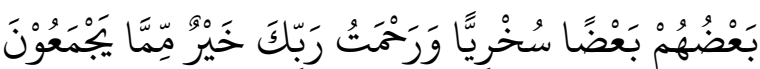

Artinya: "Apakah mereka yang membagi-bagi rahmat Tuhanmu? Kamilah yang menentukan penghidupan mereka dalam kehidupan dunia, dan Kami telah meninggikan sebagian mereka atas sebagian yang lain beberapa derajat, agar sebagian mereka dapat memanfaatkan sebagian yang lain. Dan rahmat Tuhanmu lebih baik dari apa yang mereka kumpulkan." (QS. AzZukhruf:32)." 
Sebagai SDM syariah, landasan yang paling mendasar ialah iman kepada Allah, yang sadar bahwa setiap kegiatan dan tindakannya dalam bekerja selalu diawasi oleh Allah dan tujuan utamanya hanya untuk Allah. Ketika iman menjadi landasan bagi seseorang dalam bekerja dan berorganisasi, maka keimanan menghadirkan beberapa hal, diantaranya adalah:

a. Cenderung memilih yang halal, bukan yang haram.

b. Cenderung menjauhi yang syubhat.

c. Cenderung pada nilai-nilai kebaikan.

d. Menghormati anak buah dan pimpinan.

e. Beretos kerja tinggi dan memperhatikan nilai-nilai kebaikan.

f. Memperhatikan etika dan norma dalam mengelola organisasi/perusahaan.

Selain iman, SDM syariah hendaknya memiliki akhlak dan moral Islami seperti karakter Nabi Muhammad. Beliau memiliki karakter amanah, fathanah, tabligh dan shidiq. Amanah adalah sikap bisa dipercaya dalam mengemban tanggung jawab yang diberikan kepadanya. Fathanah adalah sikap profesional dalam melakukan berbagai pekerjaan. Tabligh adalah sikap transparan dan bertanggung jawab terhadap setiap hal yang merupakan amanah yang diberikan kepadanya. Shidiq atau jujur yang berarti setiap SDM syariah harus terpercaya sehingga bisa diandalkan dalam melakukan pekerjaannya.

Selain akhlak dan moral, yang harus dimiliki seorang SDM syariah yaitu kompetensi. Kompetensi adalah serangkaian pengetahuan, kemampuan dan keterampilan yang dimiliki seseorang baik itu melekat pada diri manusia ataupun pemberian dari luar. Menurut Abu Fahmi kompetensi yang harus dimiliki SDM Syariah, adalah sebagai berikut:

a. Kompetensi inti, perbankan syariah membutuhkan SDM yang memiliki pandangan dan keyakinan yang sesuai dengan visi dan misi perbankan syariah.

b. Kompetensi perilaku, kemampuan SDM untuk bertindak efektif, memiliki semangat islami, fleksibel dan memiliki jiwa ingin tahu yang tinggi.

c. Kompetensi fungsional, kompetensi ini berbicara tentang background dan keahlian. SDM yang dibutuhkan adalah SDM yang memiliki dasar ekonomi syariah, operasi perbankan, administrasi keuangan dan analisa keuangan.

d. Kompetensi manajerial, SDM yang mampu menjadi team leader, cepat menangkap perubahan dan mampu membangun hubungan dengan yang lain.

\section{KESIMPULAN}

Kajian pengembangan sumber daya manusia merupakan kajian yang sangat menarik karena setiap zaman manusia pasti dituntut untuk berkembang. Dalam syariah, pengembangan sumber daya manusia terdiri dari pelatihan keterampilan, pengetahuan, tingkah laku dan syariah competence.

\section{REFERENSI}

Al-Qur'anulkarim.

Amin, Riawan Amin. 2010. Menggagas Manajemen Syariah: Teori dan Praktik The Celestial Management. Jakarta: Salemba Empat. 114.

Arifin, Zainul. 2002. Dasar-Dasar Manajemen Bank Syariah. Jakarta: Alvabet. 116.

Darmawan, Cecep. 2006. Kiat Sukses Manajemen Rasulullah: Manajemen Sumber Daya Insani Berbasis Nilai-Nilai Ilahiyah. Bandung: Khazanah Intelektual. 93-98.

Fahmi, Abu. 2014. HRD Syariah Teori dan Implementasi Manajemen Sumber Daya Manusia Berbasis Syariah. Jakarta: PT Gramedia Pustaka Utama. 12.

Harun. 2017. Fiqh Muamalah. Surakarta: Muhammadiyah University Press. 3.

Hasibuan, S.P. Malayu. 2007. Manajemen Sumber Daya Manusia, Dasar-dasar dan Kunci Keberhasilan. Jakarta: PT. Gunung Agung. 70.

J. Rachbin, Didik. 2001. Pengembangan Ekonomi Sumber Daya Manusia. Jakarta: PT. Gramedia Widiasarana Indonesia. 15.

Jazuli, Ahzami Samiun. 2006. Kehidupan dalam Pandangan al-Qur'an (Jakarta: Gema Insani, 2006. 509.

Jusmaliani. 2014. Pengelolaan Sumber Daya Insani. Jakarta: PT Bumi Aksara. 100.

Mangkunegara, A. A. 2001. Manajemen Sumber Daya Manusia Perusahaan. Bandung: PT Remaja Rosda Karya. 56.

Moekijat. 1994. Pengembangan Organisasi. Bandung: Mandar Maju. 8.

Mulawarman. 2003. Sistem Pendididikan Berbasis Pelatihan Kompetensi dan Inteligensi. Jakarta: Gramedia Pustaka. 3.

Nawawi, Hadari. 2000. Manajemen Sumber Daya Manusia untuk Bisnis yang Kompetitif. Yogyakarta: Gajahmada University Press. 216.

Notoatmojo, Soekidjo. 1992. Pengembangan Sumber Daya Manusia. Jakarta: Rineka Cipta. 2-3. 
Jurnal Ilmiah Ekonomi Islam, 7(01), 2021, 411

Notoatmojo, Soekidjo. 1995. Pengembangan Sumber Daya Manusia. t. t, PT. Bank Negara Indonesia. 7.

Nugroho, Soerapto. 2004. Pelatihan dan Pendidikan: Kompetensi SDM yang Handal, Mandiri dan Profesional Jakarta: Rineka Cipta. 19.

Raharjo, Muhammad Mu'iz. 2011. Manajemen Sumber Daya Manusia yang Unggul, Cerdas \& Berkarakter Islami. Yogyakarta: Penerbit Gava Media. x-xi.

Sastradipoera, Komaruddin. 2002. Manajemen Sumber Daya Manusia: Suatu Pendekatan Fungsi Operatif. Bandung: Kappa-Sigma. 51.
Suprihanto, John. 2000. Penilaian Kinerja dan Pengembangan Sumber Daya Manusia. Yogyakarta: BPFE. 88.

Syafi'i, Nasrul Umam., Lukman Hakim, Shalat Sunnah Hikmah \& Tuntunan Praktis. Jakarta: Qultum Media. iii.

Widyahartono. 1995. Pengembangan Sumber Daya Manusia. t.t, PT. Bank Negara Indonesia. 7. 